\title{
GATOR Complex Protein NPRL3
}

National Cancer Institute

\section{Source}

National Cancer Institute. GATOR Complex Protein NPRL3. NCI Thesaurus. Code C106288.

GAT OR complex protein NPRL3 (569 aa, $64 \mathrm{kDa}$ ) is encoded by the human NPRL3 gene. This protein has no known function. 